research support from: Abbvie, Celgene, Centocor, Merck, Novartis, Consultant for: Abbvie, BMS, Boehringer-Ingelheim, Celgene, Eli Lilly, Hospira, Janssen, Merck, Novartis, Novo, Orion, Pfizer, Regeneron, Roche, and UCB, Speakers bureau: Abbvie, BMS, Boehringer-Ingelheim, Celgene, Eli Lilly, Hospira, Janssen, Merck, Novartis, Novo, Orion, Pfizer, Regeneron, Roche, and UCB

DOI: 10.1136/annrheumdis-2019-eular.4960

\section{FRI0379 LONG-TERM EVALUATION OF SECUKINUMAB 150 MG IN ANKYLOSING SPONDYLITIS: 5-YEAR END-OF-STUDY EFFICACY AND SAFETY RESULTS FROM A PHASE 3 TRIAL}

Helena Marzo-Ortega ${ }^{1}$, Joachim Sieper ${ }^{2}$, Alan Kivitz ${ }^{3}$, Ricardo Blanco ${ }^{4}$, Martin Cohen $^{5}$, Karel Pavelka ${ }^{6}$, Eumorphia Maria Delicha ${ }^{7}$, Anna Stefanska ${ }^{8}$, Hanno Richards ${ }^{7}$, Susanne Rohrer . ${ }^{1}$ NIHR Leeds Biomedical Research Centre, Leeds Teaching Hospitals NHS Trust, University of Leeds, Leeds, United Kingdom; ${ }^{2}$ University Clinic Benjamin Franklin, Berlin, Germany, ${ }^{3}$ Altoona Center for Clinical Research, Duncansville, United States of America; ${ }^{4}$ Hospital Universitario Marqués de Valdecilla, Santander, Spain; ${ }^{5}$ McGill University, Montreal, Canada; ${ }^{6}$ Institute of Rheumatology and Department of Rheumatology, 1st Faculty of Medicine, Charles University in Prague, Prague, Czech Republic; ' Novartis Pharma AG, Basel, Switzerland; ${ }^{8}$ Novartis Ireland Limited, Dublin, Ireland

Background: Evaluation of long-term efficacy and safety for treatments for ankylosing spondylitis (AS) is important. Secukinumab, a fully human monoclonal antibody that directly inhibits interleukin-17A, has shown significant and sustained improvement in the signs and symptoms of AS through 3 years in the MEASURE 2 study (NCT01649375). ${ }^{1}$

Objectives: We report the 5-year end-of-study results of subcutaneous (s. c.) secukinumab $150 \mathrm{mg}$ in the MEASURE 2 study.

Methods: AS patients (pts; $N=219$ ) were randomised to receive s.c. secukinumab $150 \mathrm{mg}, 75 \mathrm{mg}$ or placebo at baseline, Weeks (Wks) 1, 2 and 3 and every 4 wks from Wk 4 . At Wk 16, placebo-treated pts were re-randomised to receive secukinumab $150 / 75 \mathrm{mg}$. Efficacy results are reported for pts initially randomised to secukinumab $150 \mathrm{mg}$ and those who switched from placebo to secukinumab $150 \mathrm{mg}$ at $\mathrm{Wk} 16$ ( $\mathrm{N}=$ 106). An optional dose escalation from secukinumab $75 \mathrm{mg}$ to $150 \mathrm{mg}$ was initiated beginning Wk 140. Outcome measures at Wk 260 included ASAS20/40, BASDAI50, BASMI, BASFI, SF-36 PCS and ASAS partial remission. Analyses stratified by anti-TNF status (anti-TNF-naïve and antiTNF inadequate response [IR]) were performed. Safety analysis included all pts who received $\geq 1$ dose of secukinumab. Results are reported as observed.

Results: The retention rate to Wk 260 was $77 \%(82 / 106)$ for secukinumab $150 \mathrm{mg}$. Sustained efficacy was observed with secukinumab $150 \mathrm{mg}$ across all endpoints through 5 years (Table). Improvements were maintained regardless of prior exposure to anti-TNF therapy with greater responses in anti-TNF-naïve pts. A total of 49 pts on secukinumab 75 $\mathrm{mg}(46.7 \%)$ escalated dose to $150 \mathrm{mg}$ after Wk 140; efficacy responses improved in pts whose dose was escalated. Over the entire study period, the mean exposure $( \pm S D)$ to secukinumab was $1459.1 \pm 597.8$ days. Exposure-adjusted incidence rates (per 100 pt-years) with any secukinumab dose for selected adverse events were: Candida infections (1.0), Crohn's disease (0.5), major adverse cardiovascular events (0.7), uveitis (0.5), and malignant/unspecified tumours (0.5).

Conclusion: Secukinumab $150 \mathrm{mg}$ provided sustained improvement in the signs, symptoms, and physical function in pts with AS through 5 years of treatment. The safety profile of secukinumab remained consistent with previous reports. $^{1-3}$

\section{REFERENCES:}

[1] Marzo-Ortega, et al. RMD Open. 2017;3:e000592; 2. Marzo-Ortega, et al. Ann Rheum Dis. 2016;75:812-3; 3. Baraliakos X, et al. Clin Exp Rheumatol 2017.

Disclosure of Interests: Helena Marzo-Ortega Grant/research support from: Janssen, Novartis and Pfizer, Consultant for: AbbVie, Celgene, Janssen, Eli-Lilly, Novartis and UCB, Speakers bureau: AbbVie, Celgene, Janssen, Eli-Lilly, Novartis and UCB, Joachim Sieper Consultant for: Abbvie, Böhringer Ingelheim, Janssen, Lilly, Merck, Mylan, Novartis, Pfizer, UCB., Speakers bureau: Abbvie, Böhringer Ingelheim, Janssen, Lilly, Merck, Mylan, Novartis, Pfizer, UCB., Alan Kivitz Shareholder of: Novartis, Consultant for: Abbvie, Janssen, Pfizer, UCB, Genzyme, Sanofi, Regeneron, Boehringer Ingelheim, Sun Pharma Advanced Research, Flexion., Paid instructor for: Celgene, Horizon, Merck, Novartis, Pfizer, Genzyme, Sanofi, Regeneron, Speakers bureau: Celgene, Horizon, Merck and Genetech,
Flexion, Ricardo Blanco Grant/research support from: Abbvie, MSD and Roche, Consultant for: Abbvie, Pfizer, Roche, Bristol-Myers, Janssen and MSD, Speakers bureau: Abbvie, Pfizer, Roche, Bristol-Myers, Janssen and MSD, Martin Cohen Consultant for: AbbVie, Amgen, Celgene, Lilly, Novartis, Pfizer, Sandoz, Sanofi and UCB, Speakers bureau: AbbVie, Amgen, Celgene, Janssen, Merck, Novartis and Pfizer, Karel Pavelka: None declared, Eumorphia Maria Delicha Employee of: Novartis, Anna Stefanska Shareholder of: Novartis, Employee of: Novartis, Hanno Richards Shareholder of: Novartis Pharma AG, Employee of: Novartis Pharma AG, Susanne Rohrer Shareholder of: Novartis, Employee of: Novartis

DOI: 10.1136/annrheumdis-2019-eular.5531

Table. Efficacy Endpoints with Secukinumab $150 \mathrm{mg}$ at Week 260 (5 year)

\begin{tabular}{lccc}
\hline Variable & \multicolumn{3}{c}{ Secukinumab 150 $\mathbf{~ m g}^{\mathbf{1}}$} \\
\cline { 2 - 4 } & $\begin{array}{l}\text { Total } \\
\mathbf{N}=\mathbf{1 0 6}\end{array}$ & $\begin{array}{c}\text { Anti-TNF-naïve } \\
\mathbf{N}=\mathbf{6 6}\end{array}$ & $\begin{array}{c}\text { Anti-TNF-IR } \\
\mathbf{N}=\mathbf{4 0}\end{array}$ \\
\hline ASAS20 $^{2}$ & $69.9(83)$ & $73.7(57)$ & $61.5(26)$ \\
ASAS40 $^{2}$ & $54.2(83)$ & $63.2(57)$ & $34.6(26)$ \\
ASAS-Partial Remission $^{2}$ & $25.3(83)$ & $28.1(57)$ & $19.2(26)$ \\
BASDAI50 $^{2}$ & $53.0(83)$ & $56.1(57)$ & $46.2(26)$ \\
BASMI $^{3}$ & $-0.7 \pm 1.2(80)$ & - & - \\
BASFI $^{3}$ & $-2.8 \pm 2.6(83)$ & - & - \\
SF-36 PCS $^{3}$ & $8.0 \pm 8.5(79)$ & $8.5 \pm 8.9(56)$ & $6.8 \pm 7.4(23)$ \\
\hline
\end{tabular}

Data are reported as observed; ${ }^{1}$ Includes placebo switchers; ${ }^{2} \%$ responders $(\mathrm{n}) ;{ }^{3}$ mean change from baseline \pm SD (n); IR, inadequate response; $N$, total number of randomised patients; n, number of evaluable patients; TNF, tumour necrosis factor

\section{FRI0380 SECUKINUMAB PROVIDES SUSTAINED IMPROVEMENT OF ENTHESITIS IN PATIENTS WITH ANKYLOSING SPONDYLITIS: POOLED ANALYSIS OF FOUR PIVOTAL PHASE 3 STUDIES}

Georg Schett ${ }^{1}$, Xenofon Baraliakos ${ }^{2}$, Filip van den Bosch ${ }^{3}$, Atul Deodhar ${ }^{4}$, Lianne S. Gensler ${ }^{5}$, Mikkel $_{\text {Østergaard }}$, Shital Agawane ${ }^{7}$, Ayan Das Gupta ${ }^{7}$, Shephard Mpofu ${ }^{8}$, Todd Fox ${ }^{9}$, Adam Winseck ${ }^{9}$, Abhijit Shete ${ }^{8}$, Brian Porter ${ }^{9}$. ${ }^{1}$ Friedrich Alexander University Erlangen-Nuremberg, Department of Internal Medicine, Erlangen, Germany; ${ }^{2}$ Rheumazentrum Ruhrgebiet, and Ruhr University Bochum, Herne, Germany; ${ }^{3}$ Ghent University Hospital, Ghent, Belgium; ${ }^{4}$ Oregon Health and Science University, Oregon, United States of America; ${ }^{5}$ University of California, San Francisco, United States of America; ${ }^{6}$ Copenhagen Center for Arthritis Research (COPECARE), University of Copenhagen, Copenhagen, Denmark; ${ }^{7}$ Novartis Healthcare Pvt Ltd, Hyderabad, India; ${ }^{8}$ Novartis Pharma AG, Basel, Switzerland; ${ }^{9}$ Novartis Pharmaceuticals Corporation, East Hanover, United States of America

Background: Enthesitis can be a debilitating extra-articular spondyloarthritis (SpA) manifestation and cause of considerable pain and reduced quality of life/physical function. ${ }^{1,2}$

Objectives: To evaluate the effect of secukinumab (SEC) on axial and peripheral enthesitis in ankylosing spondylitis (AS) patients (pts) with baseline enthesitis (BLE) across all Maastricht AS EnthesiS (MASES) sites $(\mathrm{N}=13)$, axial MASES sites $[\mathrm{N}=11 ; 13$ MASES minus Achilles tendons (AT); AxS], peripheral sites ( $N=6$; $A T$ + lateral condyles of humerus/femur; PS) and the AT ( $\mathrm{N}=2 ; \mathrm{AT})$ at Weeks (W) 16 and 52.

Methods: This post hoc analysis pooled data across 4 SEC studies in AS (MEASURE 1-4) from pts originally randomised to SEC $150 \mathrm{mg}$ (approved dose in AS), 300mg (MEASURE 3 only), or placebo (PBO) with BLE (MASES >0). Study designs have been reported previously. Evaluations include mean change from $\mathrm{BL}$ in MASES score, complete resolution (CR; MASES $=0$ ) and improvement from BL in MASES score of $\geq 5$ counts. Mixed-effect model repeat measurement (MMRM) analysis was done on change from BL in MASES score and non-responder imputation for resolution of enthesitis at W16; data are reported as observed at W52.

Results: A total of $355(70.4 \%), 58(76.3 \%)$, and $280(72 \%)$ pts had BLE in $150 \mathrm{mg}, 300 \mathrm{mg}$ and $\mathrm{PBO}$ groups, respectively. BL characteristics were generally comparable across groups. At W16, mean change from $\mathrm{BL}$ for overall MASES and at AxS was greater for SEC $150 \mathrm{mg} \quad(-2.4$ and -2.3$)$ and $300 \mathrm{mg}(-2.9$ and -2.9$)$ vs PBO $(-1.9$ and $-1.8 ; P<0.05$ and $<0.01)$. At $\mathrm{W} 16$, pts treated with SEC $150 \mathrm{mg}(40.8 \%$ and $42.7 \%)$ and $300 \mathrm{mg}(36.2 \%$ and $42.1 \%)$ vs PBO $(28.9 \%$ and $30.1 \%)$ achieved CR of enthesitis based on overall MASES and at AxS. SEC150mg and $300 \mathrm{mg}$ were also consistently associated with higher mean change in MASES and CR of enthesitis at PS and individually at AT vs PBO. A higher proportion of pts treated with SEC $150 / 300 \mathrm{mg}$ vs PBO achieved a higher threshold of improvement ( $\geq 5$ counts) in overall MASES at W16. Further improvements were observed for all endpoints at W52 (Table). 